5-1-2015

\title{
Book Review: The Holodomor Reader: A Sourcebook on the Famine of 1932-1933 in Ukraine
}

Laura C. Collins

George Mason University

Follow this and additional works at: https://digitalcommons.usf.edu/gsp

\section{Recommended Citation}

Collins, Laura C. (2015) "Book Review: The Holodomor Reader: A Sourcebook on the Famine of 1932-1933 in Ukraine," Genocide Studies and Prevention: An International Journal: Vol. 9: Iss. 1: 114-115. DOI:

http://dx.doi.org/10.5038/1911-9933.9.1.1320

Available at: https://digitalcommons.usf.edu/gsp/vol9/iss1/11

This Book Review is brought to you for free and open access by the Open Access Journals at Digital Commons @ University of South Florida. It has been accepted for inclusion in Genocide Studies and Prevention: An International Journal by an authorized editor of Digital Commons @ University of South Florida. For more information, please contact digitalcommons@usf.edu. 


\title{
Book Review: The Holodomor Reader: A Sourcebook on the Famine of 1932-1933
}

in Ukraine

\author{
Laura C. Collins \\ George Mason University \\ Arlington, VA, USA
}

The Holodomor Reader: A Sourcebook on the Famine of 1932-1933 in Ukraine

Edited by Bohdan Klid and Alexander J. Motyl

Edmonton: Canadian Institute of Ukrainian Studies Press, 2012. 386pp. US\$34,95

Reviewed by Laura C. Collins

George Mason University, Arlington, VA, USA

The official wall of silence erected around the events that precipitated the sentencing to death of what some commentators have approximated at 4 million people between the autumn of 1932 and the summer of 1933 in the Ukrainian socialist soviet republic and the Kuban region of southern Russia - an area in the northern Caucasus that was densely populated by ethnic Ukrainians - only began to crumble toward the end of the 1980s with the implementation of Gorbachev's Perestoika. Further, it was only following the dissolution of the Soviet Union and the subsequent emergence of various official documentation, once hidden, and harrowing personal accounts, once whispered, relating to what has come to be viewed by some as the most notorious of the pan-Soviet famines during the period of the early 1930s that a burgeoning body of scholarly literature began to appear. Subsequently termed the Holodomor, the literature on this famine has sought to analyze the political antecedents and those exacerbating factors that further deepened the severity of the famine felt by ethnic Ukrainians, and crucially the positioning of the Stalinist regime.

Klid and Motyl's carefully crafted compilation is an attempt, which is wholly achieved, to piece together in one place for both experts and the layperson alike excerpts of some of the most prominent scholarly literature and official documentation along with eyewitness accounts and testimonies dealing directly with the Holodomor. To that effect, following a comprehensive introductory chapter presented by Klid and Motyl, the editors then lay out their volume in six pertinently themed sections. Beginning with excerpts from scholarship on the Holodomor, given the debate concerning the applicability of the charge of genocide to this famine, the documents that follow the scholarship section contain various legal evaluations and resolutions that have emerged directly related to the interpretation of the Holodomor as genocide. The complementary third and fourth sections contain eyewitness accounts. The former contains accounts provided by journalists and traveler writers of the time, in addition to those given by individuals within the Stalinist regime at various levels of its hierarchy. The latter section is wholly dedicated to detailing the accounts of survivors. The fifth section of the volume, simply entitled "Documents" is comprised of both official Soviet archival records along with foreign government documentation. To end, the editors dedicate the sixth section to a vast array of literary works that has emerged dealing with this famine. Much of the initial benefit, therefore, of this work emanates from the diversity and richness of the excerpts chosen, thanks in large part to the skillful navigation of the editors of the myriad political and linguistic constraints previously associated with the accessibility of the documentation. The resultant effect of which makes this a highly credible and indispensible sourcebook for the intended interdisciplinary audience of newcomers and experts.

Emphasis must be given, however, to the dual overarching impetus for this work as laid out by the editors in the introductory pages, which is both one of scholarship and one of specifically advancing the interpretation of the "Holodomor as genocide" (xxxi). Noting their belief that this interpretation will prevail through an appeal to "the normative and the political zeitigeist," the editors note the likely probability of those "neutral" among the readership accepting this interpretation, while characterizing those who refute it as "diehard skeptic[s]" or as having "a political agenda" (xxxi). Lest one forget that the application of the term genocide has been equally advanced for intended political purposes. Relevant today in light of the crisis that continues to rage 
in Ukraine, it is noteworthy to reflect, therefore, on the potential for the politicization of the term genocide, as applied to the Holodomor to obscure the advancement of interdisciplinary scholarship and an understanding of the antecedents and aggravating factors, in conjunction with the role of the Soviet regime.

That said, however, the attention with which the editors have paid to compiling the first section of their sourcebook dedicated to scholarship merits highlighting. The preliminary section starts by tracing the two dominant schools of thought that have emerged dealing with the Holodomor. This first school of thought comprises of works concluding that this famine may be viewed through the prism of genocide as a result of the policies implemented by the Stalinist regime stemming from the early 1930s. These works point to the fact that the policies had as their intent from their initial conception a dual purpose. First, the Stalinist regime sought to dismantle the particularly entrenched peasant resistance to the policy of forced collectivization and its associated grain procurement campaign in the Ukrainian socialist soviet republic and the Kuban region where there was a deep culture of individual farming traditions. Second, the specter of Ukrainian nationalism, the core of which was found in within the peasantry-the "kulaks," was perceived by the Bolsheviks as one of the most powerful factors that had the potential to thwart the transformative vision Stalin had for his communist empire. To that effect, Stalin, in the early 1930s set forth a plan intended to destroy the Ukrainian nation through decimation of the peasantry. In contrast, while the second school of thought neither dismisses the criminality nor the pervasive nature of the famine in the Ukrainian socialist soviet republic and the Kuban, these works do not categorize the events as genocide, but rather conclude that this famine cannot be viewed as distinct from the complex matrix of the panSoviet experience of famines between 1931-1933, that were impacted by several factors.

Most pertinently, however, the beginning section of Klid and Motyl's sourcebook also introduces a third subsection of literature pertaining to more recent scholarship that has endeavored to refine and bridge traditional debates and insights in light of newly disclosed documentation. The centrality of the indisputable national dimension of the famine in the Ukrainian socialist soviet republic and the Kuban region, which is prominent in other scholarship is further brought to the fore by these works, but also, as an excerpt from the work of Italian scholar Andrea Graziosi pertinently conveys, it is through comparison with the other Soviet famines taking place at the same time that the distinct and changing character of the Ukrainian case of starvation, particularly from the autumn of 1932 onwards, becomes apparent. From this point, starvation, which was already somewhat present in the both areas was wielded as a weapon by the Stalinist regime to destroy the Ukrainian nation. (19-26).

The official soviet documentation contained within Klid and Motyl's volume wholly serves to reiterate the threat posed by the Ukrainian nation as perceived by Stalin and, therefore, the urgent necessity of using any and all means possible to transform Ukraine into an exemplary soviet republic, as an excerpt from Stalin to one of his associates, Kaganovich is testament (p. 239240). Moreover, the intended purpose of the unrelenting priority placed on the grain procurement campaign throughout Ukraine and the Kuban and the intention to strip peasants of all remnants of sustenance is also apparent as evidence in the correspondence sent by the Ukrainian Communist Party Secretary Stansalv Kosior, which ordered an immediate relinquishing of "all available reserves, including so-called sowing seed" for the purposes of reaching the grain procurement levels (p.251).

The significance of this contribution, therefore, to the study of the Holodomor lies not only within the pages of the compilation, which taken in sum capture the true horror of the months between the autumn of 1932 and the summer of 1933, but also in the scholarship and academic debates that they will likely stimulate across disciplines. Indeed, while the editors masterfully achieve in creating an accessible book for newcomers to the subject, those immersed in scholarship on the Holodomor or more broadly in the study of the history and politics of communism and famines will benefit from previously inaccessible documentation. In sum, as a well written, multidimensional, and creative compilation of a most serious and under researched areas particularly within scholarship on genocide, Kild and Motyl's The Holodomor Reader: A Sourcebook on the Famine of 1932-1933 in Ukraine, is a recommended reading that demands critical scholarly attention. 